\title{
EDITORS' NOTE: First Issue with Cambridge University Press
}

We are proud to introduce the first issue of the Foreign Policy Bulletin to be published by Cambridge University Press. The Bulletin's core mission remains the same as it was when it was launched in July 1990: to be the leading reference periodical providing primary source documentation of critical developments in United States foreign policy and international affairs.

This issue, the first of Volume 15, covers events in Fall 2003. In the four issues comprising Volume 15, we will bridge the gap in coverage of events since the last issue of the Bulletin published with Transnational Publishers (Volume 14, Issue 3/4), so that the first issue of Volume 16 will cover events in the Fall of 2005.

All of us at the Foreign Policy Bulletin are excited to be working with Cambridge University and we plan to announce new features of the Bulletin in the future, such as electronic access and archival search capabilities, that will enhance our ability to bring you the most thorough primary source coverage of U.S. foreign policy.

We welcome readers' comments and feedback about the Bulletin, and invite email to us at the email addresses below.

Sincerely,

Philip Auerswald

auerswald@gmu.edu
Andrew Wolff

awolff@sais-jhu.edu

Iraq: U.S. Seeks Cooperation in Rebuilding Iraq

3 September 2-October 15: U.S. campaigns for international legitimacy; Kofi Annan Questions U.S. pre-emption policy; David Kay submits report on Iraq WMD

65 October 16-November 27: U.N. resolution 1511 urges International community to contribute assistance to Iraq, U.S. raises reconstruction funds at Madrid Donors Conference, Coalition and Iraqi representatives agree on political progress plan

\section{The Middle East}

126 U.S. vetoes U.N. resolution condemning Israeli security barrier; Iran agrees to cooperate with IAEA

Africa

175 President Bush promotes HIV Initiative \& Tours Africa; U.S. forces Liberian President Charles Taylor to resign

North Korea

231 North Korea and Bush Administration exchange barbs; North Korea proceeds with enrichment program

\section{Trade}

245 U.S. Explains Failures at Cancun WTO negotiations, Repeals Steel Tariffs Following Adverse WTO Ruling

258 List of Documents

261 Index 